\title{
An Assessment of the Service History and Corrosion Susceptibility of Type IV Waste Tanks
}

\author{
B. J. Wiersma \\ Savannah River National Laboratory \\ Materials Science and Technology Directorate
}

Publication Date: September 2008

This document was prepared in conjunction with work accomplished under Contract No. DEAC09-08SR22470 with the U. S. Department of Energy

\section{We Put Science To Work}

The Savannah River National Laboratory is managed and operated for the U.S. Department of Energy by

SAVAN NAH RIVER NUCLEAR SOLUTIONS, LLC AIKEN, SC USA 29808 -SRNL.DOE.GOV 


\section{DISCLAIMER}

This report was prepared under an agreement with and funded by the U. S. Government. Neither the U. S. Government or its employees, nor any of its contractors, subcontractors or their employees, makes any express or implied: 1 . warranty or assumes any legal liability for the accuracy, completeness, or for the use of results of such use of any information, product or process disclosed; or 2. representation that such use or results of such use would not infringe privately owned rights; or 3. endorsement or recommendation of any specifically identified commercial product, process or service. Any views and opinions of authors expressed in this work do not necessarily state or reflect those of the United States Government, or its contractors, or subcontractors. 
SRNS-STI-2008-00096

DOCUMENT: $\quad$ SRNS-STI-2008-00096

TITLE:

An Assessment of the Service History and Corrosion Susceptibility of Type IV Waste Tanks

\section{APPROVALS}

Date:

B. J. Wiersma, Author

Materials Performance and Corrosion Technology

Materials Science and Technology

Savannah River National Laboratory

Date:

P.E. Zapp, Technical Reviewer

Materials Performance and Corrosion Technology

Materials Science and Technology

Savannah River National Laboratory

Date:

K.H. Subramanian, Manager

Materials Performance and Corrosion Technology

Materials Science and Technology

Savannah River National Laboratory
C.E. Blair, Manager

H\&F Tank Farm Engineering Mechanical Engineering

Liquid Waste Organization

\author{
A. S. Plummer, Customer \\ H\&F Tank Farm Engineering \\ Mechanical Engineering \\ Liquid Waste Organization
}

Date:

Date:

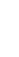

Date:

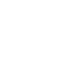


SRNS-STI-2008-00096

Table of Contents

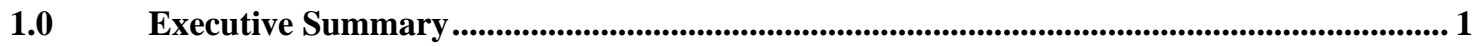

$2.0 \quad$ Introduction .................................................................................................................................. 1

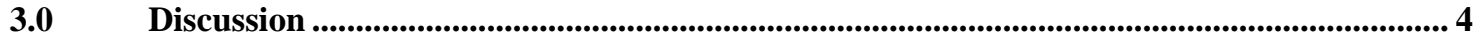

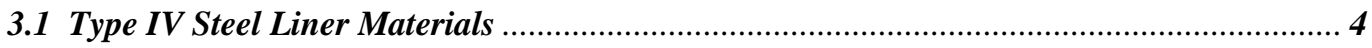

3.2 Type IV Service History .................................................................................................................... 9

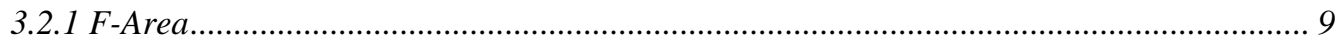

3.2.2 H-Area ................................................................................................................................................ 12

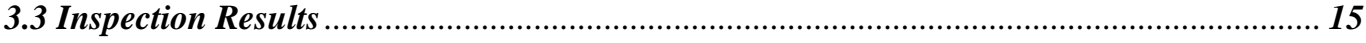

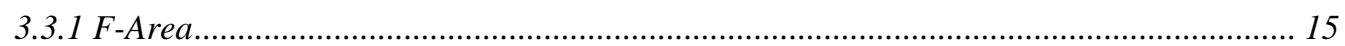

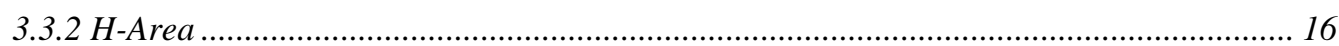

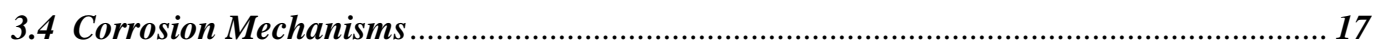

4.0 Conclusions.................................................................................................................................................. 22

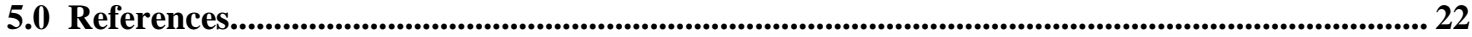




\section{An Assessment of the Service History and Corrosion Susceptibility of Type IV Waste Tanks}

\subsection{Executive Summary}

Type IV waste tanks were designed and built to store waste that does not require auxiliary cooling. Each Type IV tank is a single-shell tank constructed of a steel-lined pre-stressed concrete tank in the form of a vertical cylinder with a concrete domed roof. There are four such tanks in F-area, Tanks 17-20F, and four in H-Area, Tanks 21-24H. Leak sites were discovered in the liners for Tanks 19 and 20F in the 1980's. Although these leaks were visually observed, the investigation to determine the mechanism by which the leaks had occurred was not completed at that time. Therefore, a concern was raised that the same mechanism which caused the leak sites in the Tanks in F-area may also be operable in the H-Area tanks.

Data from the construction of the tanks (i.e., certified mill test reports for the steel, no stressrelief), the service history (i.e., waste sample data, temperature data), laboratory tests on actual wastes and simulants (i.e., electrochemical testing), and the results of the visual inspections were reviewed. The following observations and conclusions were made:

1) Comparison of the compositional and microstructural features indicate that the $\mathrm{A} 212$ material utilized for construction of the H-Area tanks are far more resistant to SCC than the A285 materials used for construction of the F-Area tanks.

2) A review of the materials of construction, temperature history, service histories concluded that F-Area tanks likely failed by caustic stress corrosion cracking.

3) The environment in the F-Area tanks was more aggressive than that experienced by the H-Area tanks.

4) Based on a review of the service history, the H-Area tanks have not been exposed to an environment that would render the tanks susceptible to either nitrate stress corrosion cracking (i.e., the cause of failures in the Type I and II tanks) or caustic stress corrosion cracking.

5) Due to the very dilute and uninhibited solutions that have been stored in Tank $23 \mathrm{H}$, vapor space corrosion has occurred on some of areas of the liner. The mild pitting that was observed is broad and shallow and has no structural impact. Further significant pit growth has not been observed since the 1980's.

\subsection{Introduction}

The Type IV tanks were designed for storing waste that does not require auxiliary cooling [1]. Each Type IV tank is a single-shell tank constructed of a steel-lined pre-stressed concrete tank in the form of a vertical cylinder with a concrete domed roof (see Figure 1). Each tank holds 1.3 million gallons, is 85 feet in diameter, and is 34 feet high. Details of the tank wall are shown in Figure 2. Carbon steel plates, $3 / 8$ inch thick, were used to form the cylindrical sides and flat bottom portions of the steel liners. The knuckle plates at the juncture of the bottom and sidewall are 7/16 inch. Concrete was built up around the steel vessel by the "shotcrete" technique, a pneumatic method of application in which the thick semi-fluid mixture is blown through a nozzle 
to form a built-up structure. The thickness of the concrete is approximately 10 inches. The concrete dome itself is not lined with steel.

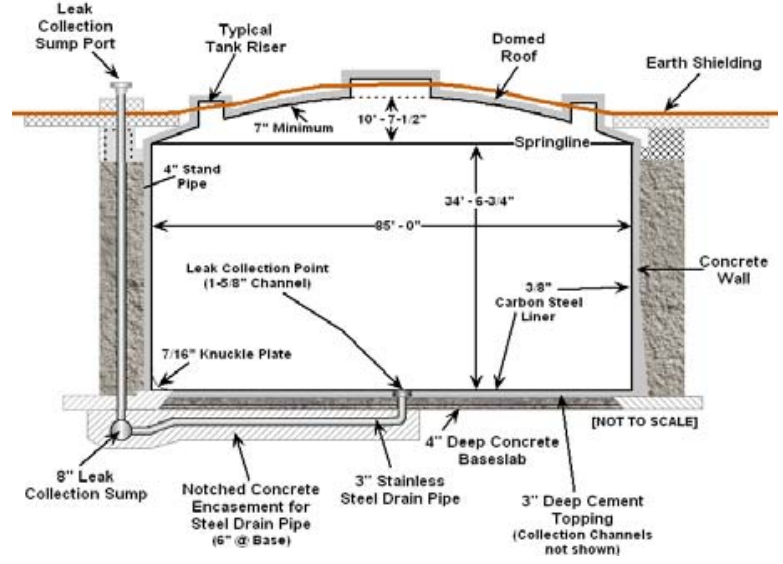

(a)

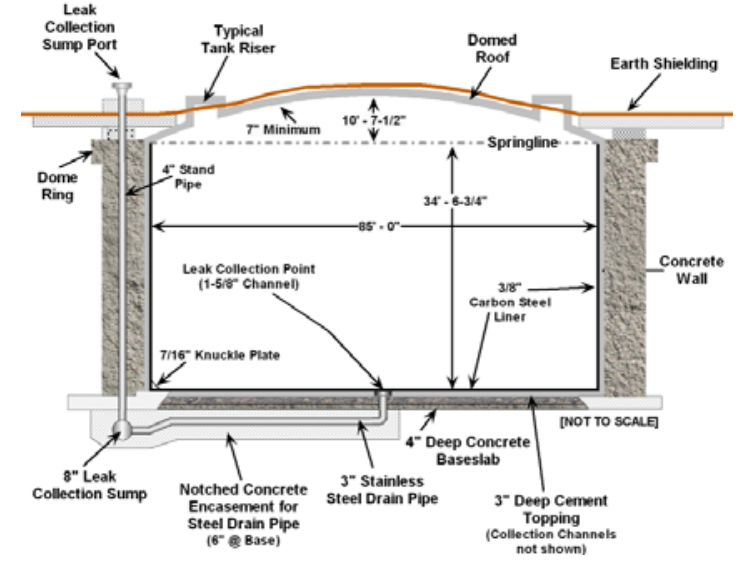

(b)

Figure 1. Design of Type IV tanks (a) F-area and (b) H-area. Note that the sidewall sump is not depicted on the $\mathrm{H}$-area tank drawing.

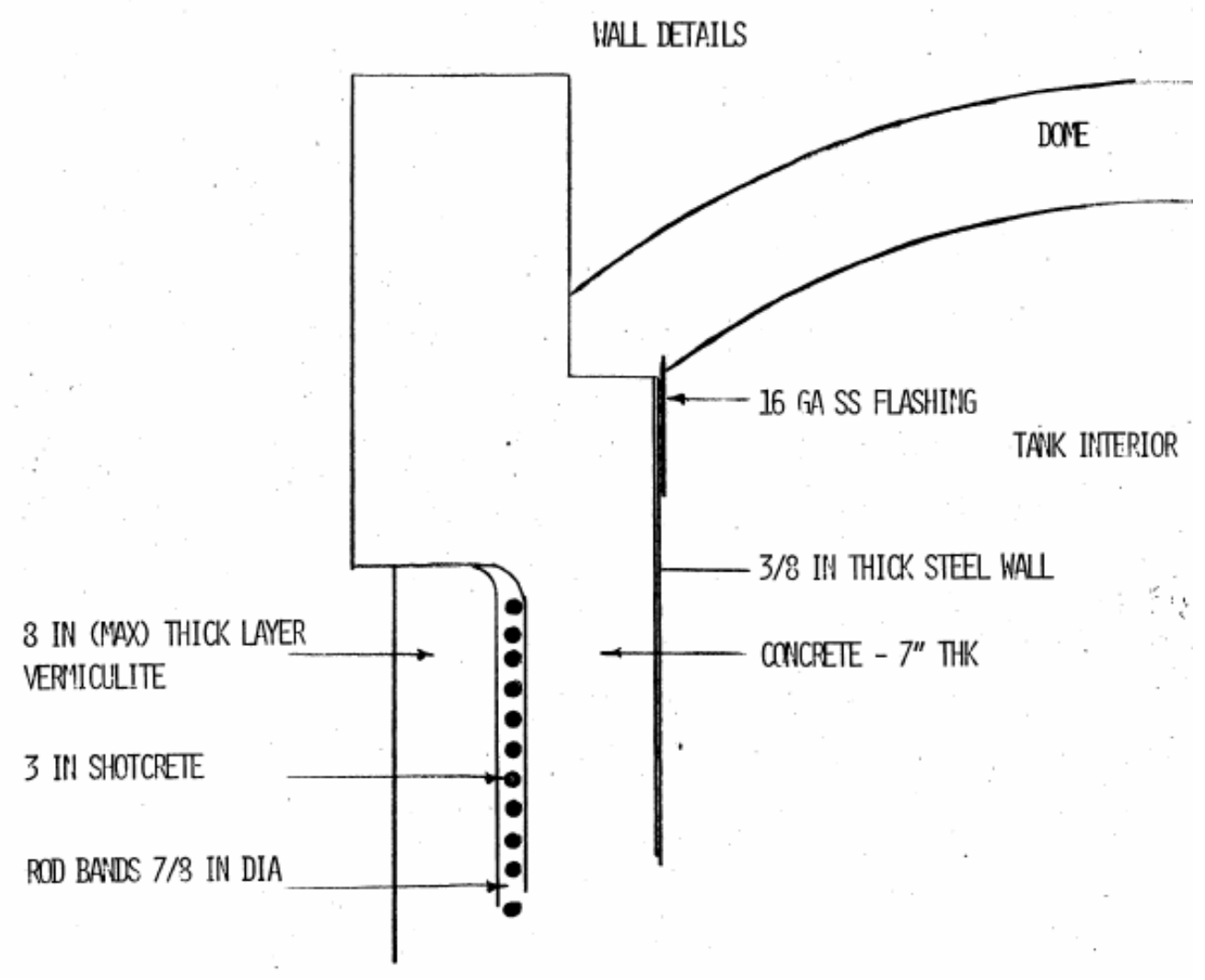

Figure 2. Details of Type IV tank sidewall design. 
Several pre-service inspections were completed: (1) all welds in the steel liners were x-rayed; (2) all of the welded tank-bottom seams and the upper seams of the knuckle rings were vacuum leak tested; and (3) each tank was hydrostatically tested by filling with water to the normal fill line before the backfilling operation.

Pre-stressing of the concrete was performed by embedding girth bands of steel under tension in the outer layer of the concrete wall, thereby applying a compressive force to the inner layers and the steel liner. As the tank was being assembled, the steel liner was stiffened with internal rings made of angle iron to retain the shape of the wall when the concrete was cast and shrunk around it. Tanks 17-20 in F-Area were pre-stressed with steel rods and turnbuckles, while Tanks 21-24 in $\mathrm{H}$-area were pre-stressed with steel wire machine-wound around the tanks at a specified tension.

Leak detection for these tanks was provided by a grid of channels in the concrete foundation, which drain to a sump outside the tank wall (see Figure 3). A four inch pipe rises to grade from the sump to allow for liquid level measurements, sampling, and pump-out of collected fluid. The $\mathrm{H}$-Area tanks have an additional leak detection feature that would detect gross leakage through the sidewall. A circumferential, open-topped drainage channel, filled with crushed stone, was installed outside the concrete tank wall adjacent to the wall foundation (see Figure 4). Two vertical pipes, $180^{\circ}$ apart, were inserted down to the channel to provide a means for detecting leakage.

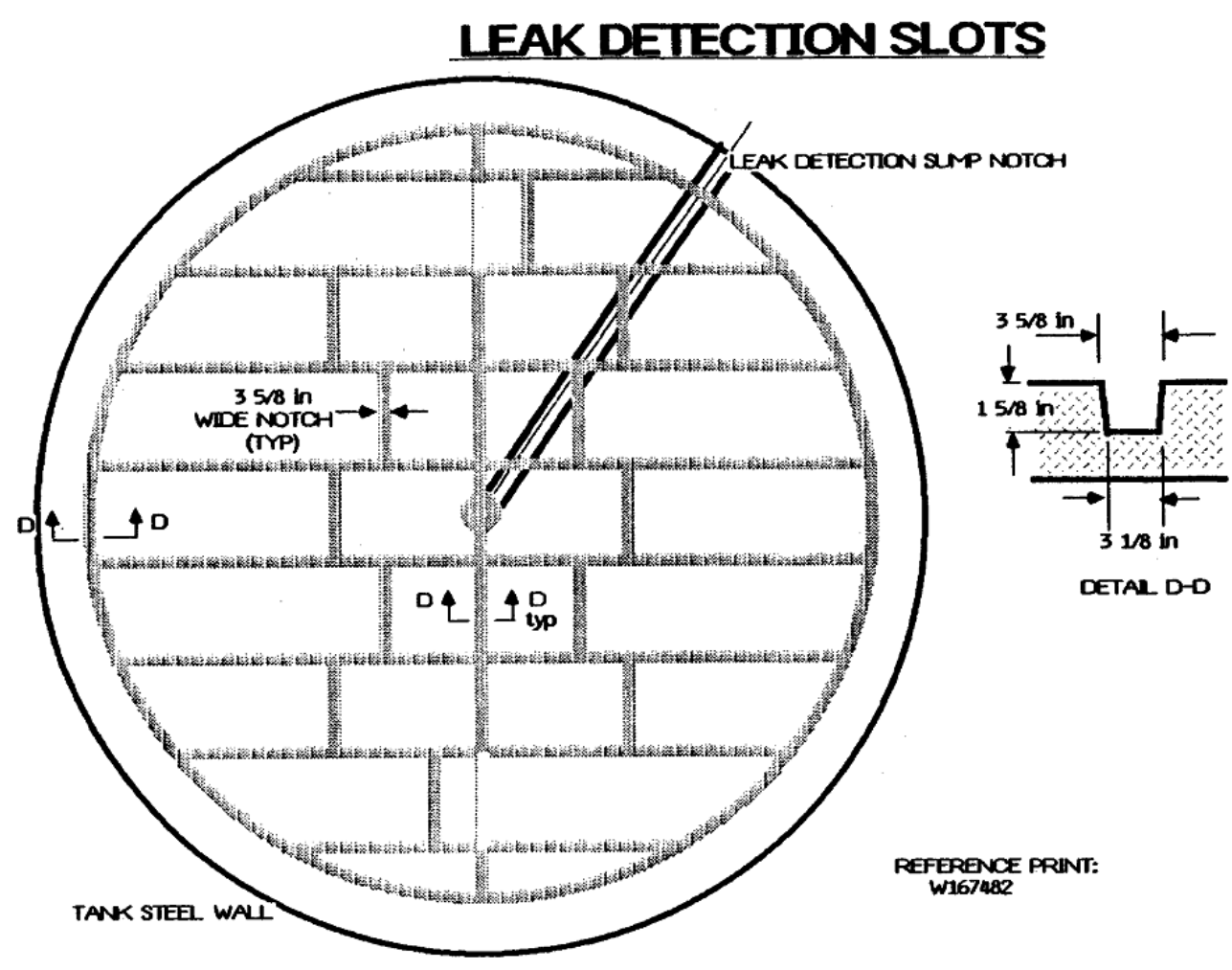

Figure 3. Leak detection slots in concrete beneath steel liner bottom. 


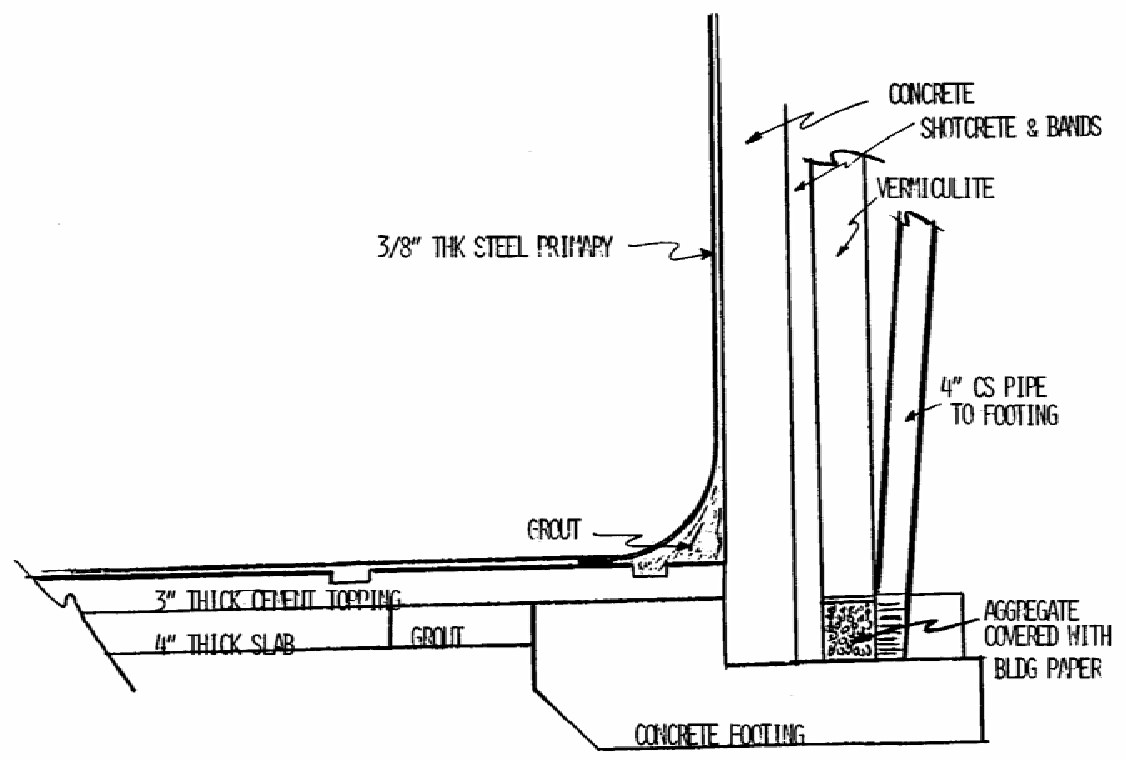

Figure 4. Sidewall sump for H-Area Type IV Tanks

\subsection{Discussion}

The materials of construction, service histories, and inspection results of the Type IV tanks were reviewed to assess their stress corrosion cracking susceptibility. The SCC susceptibility was assessed as a function of steel chemical composition and micro-structural features. The service histories were reviewed for specific environments the Type IV tanks were exposed that may lead to SCC. The variations between H-Area and F-Area tanks are discussed in detail.

\subsection{Type IV Steel Liner Materials}

The steel liner plate for the F-Area tanks is hot-rolled, semi-killed, open-hearth carbon steel, ASTM A285-54T Grade B (A285), firebox quality, suitable for submerged arc welding [2]. The liner was fabricated according to Section VIII of the 1952 ASME Boiler Code for Unfired Pressure Vessels. This grade of material was also utilized to fabricate the Type I and II waste tanks.

The steel liner plate for the H-Area tanks is hot-rolled, fully-killed, open-hearth carbon steel, ASTM A212-57T Grade B (A212), minimum carbon $0.18 \mathrm{wt} . \%$, suitable for submerged arc welding. The minimum carbon content was not required by the ASTM standard, but was included in the site specification for the material [3]. In a commentary on the design of the waste tanks [4] it was noted that, "..a higher minimum carbon content would better resist stress corrosion cracking without field stress relieving." The liner was fabricated according to Section VIII of the 1956 ASME Boiler Code for Unfired Pressure vessels. It should be noted that in 
1966 the A212 designation was discontinued and replaced by ASTM A516 (A516-70) [5]. Therefore, A516-70 and A212 are expected to have "comparable chemical and property specifications [5]." To verify this statement, the certified mill test reports for Tanks 21-24 and Tanks 29-32 and 35-37 were reviewed to determine the carbon content (i.e., chemical) and yield strength (i.e., physical) of the plates that were actually installed in the tanks $[6,7]$. (Note: ASTM A516-70 is the steel that was used to fabricate the Type III tanks at SRS, e.g., Tanks 29-32 and 35-37) As can be seen in Figure 5, the carbon content and yield strength for the H-Area Type IV tanks and the Type III tanks are very similar. Likewise, the carbon content and yield strength for the plates of steel that were installed in the F-Area tanks and the Type I and II tanks are also plotted in the same figure and are very similar.

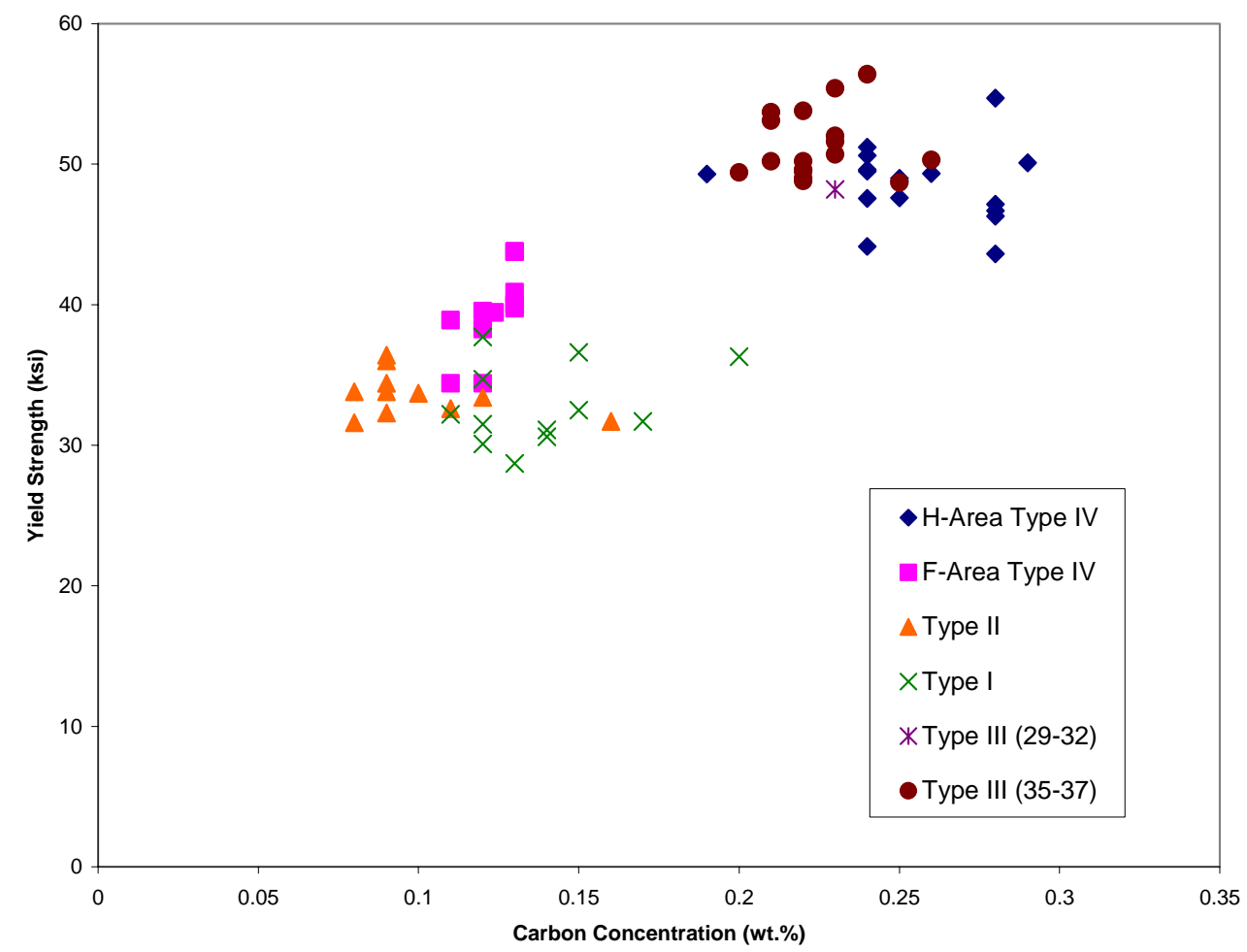

Figure 5. Plot showing the carbon content and yield strength of steels used to construct the tanks.

Stress corrosion cracking is due to the combined action of a corrosive medium and tensile stresses on a material causing cracking at lower stresses than dry cracking. A significant library of research has been completed on SCC propensity of these materials in relevant environments. A review of the literature revealed several material properties that influence the propensity for SCC in specific environments. A stressed material that cracks in an aggressive environment has micro-structural characteristics and defects that have influenced its failure. An appreciation for the influence of the chemical composition, micro-structural features, and defects within a steel and their interaction with stress and environment will provide a basis for understanding the relative susceptibility to stress corrosion cracking (SCC) of the two materials. Micrographs of A285 and A516-70 are shown in Figure 6 [8]. Although both are ferritic/pearlitic steels, there is 
a significant difference in the microstructure of the materials and the SCC behavior is variant as expected. Comparison of the compositional and micro-structural features indicate that the A212 material utilized for construction of the H-Area tanks are far more resistant to SCC than the A285 materials used for construction of the F-Area tanks.

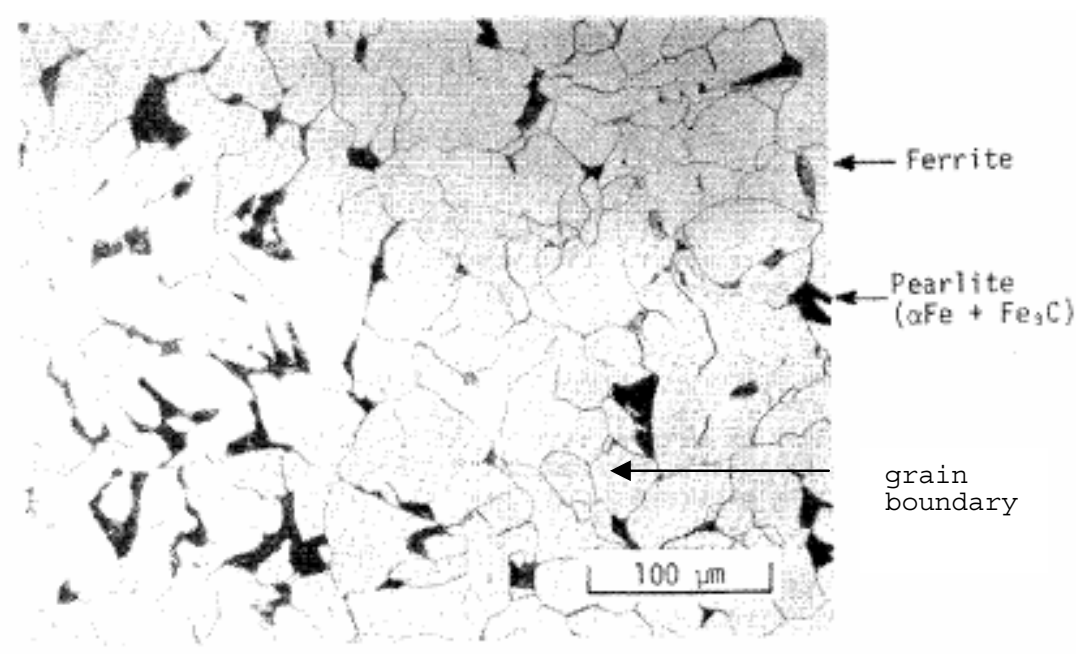

A $285-B$

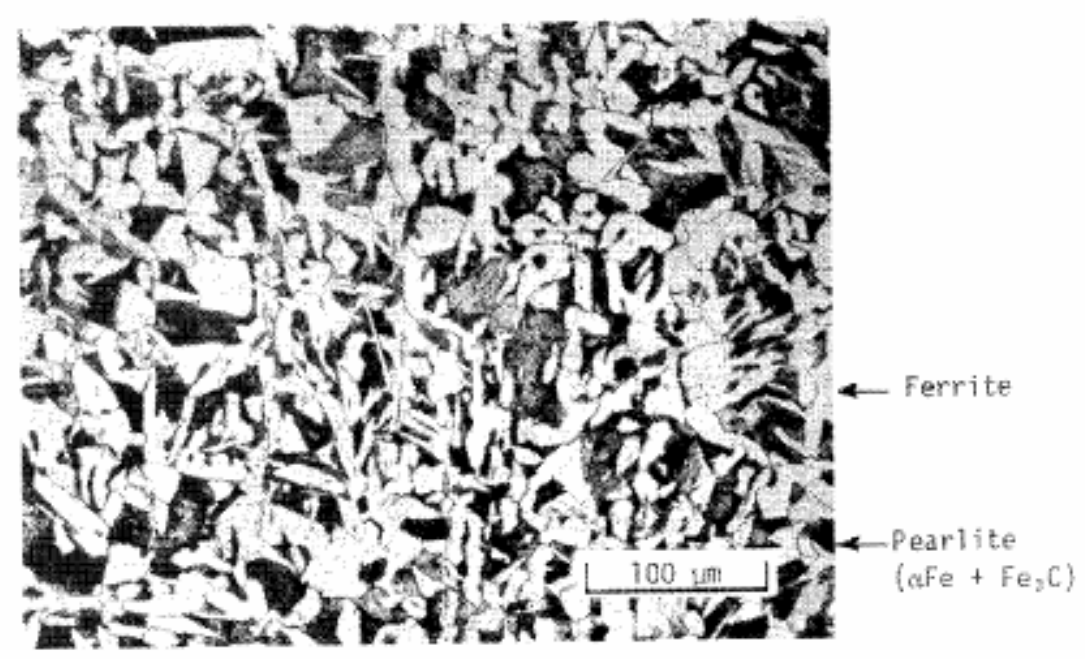

A $516-70$

Figure 6. Microstructures of A285-B and A516-70 [7].

Given that the waste environments in the tanks primarily consist of nitrate and hydroxide, defects and micro-structural characteristics of carbon steel that influence nitrate and caustic SCC are considered. Point defects in a material disturb the "perfect" crystal lattice structure of a material and create a strain field that increases the energy of the system. An example of a point defect is an interstitial atom, such as carbon, which occupies a position between normal lattice sites (see Figure 7). Carbon free iron is known to be immune from SCC in nitrate solutions. However, the introduction of a small amount of carbon increases the susceptibility to nitrate SCC until it reaches a maximum at approximately $0.03 \mathrm{wt} . \%$ carbon (See Figure 8) [9, 10]. Thereafter, the susceptibility to nitrate SCC decreases with an increase in carbon concentration. A similar 
dependence has been observed for caustic in that for carbon levels greater than $0.03 \mathrm{wt} . \%$ the susceptibility to caustic SCC decreases with an increase in carbon content [11]. However, below this carbon content a decrease in susceptibility with decreasing carbon content was not observed (See Figure 8). From Figure 5 it is observed that based on this criterion only, that the material utilized for the H-Area tanks (A212) is less susceptible to SCC than the material for the F-Area Tanks (A285).

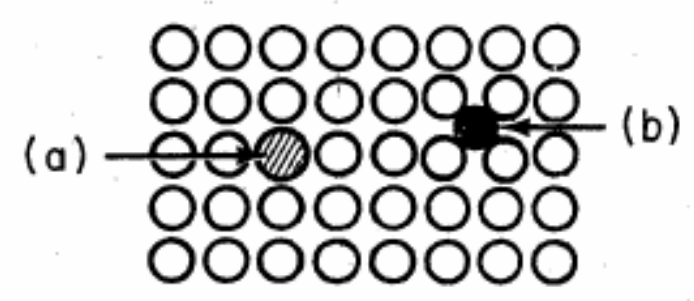

Figure 7. (a) substitutional and (b) interstitial atoms in a crystal lattice [9].

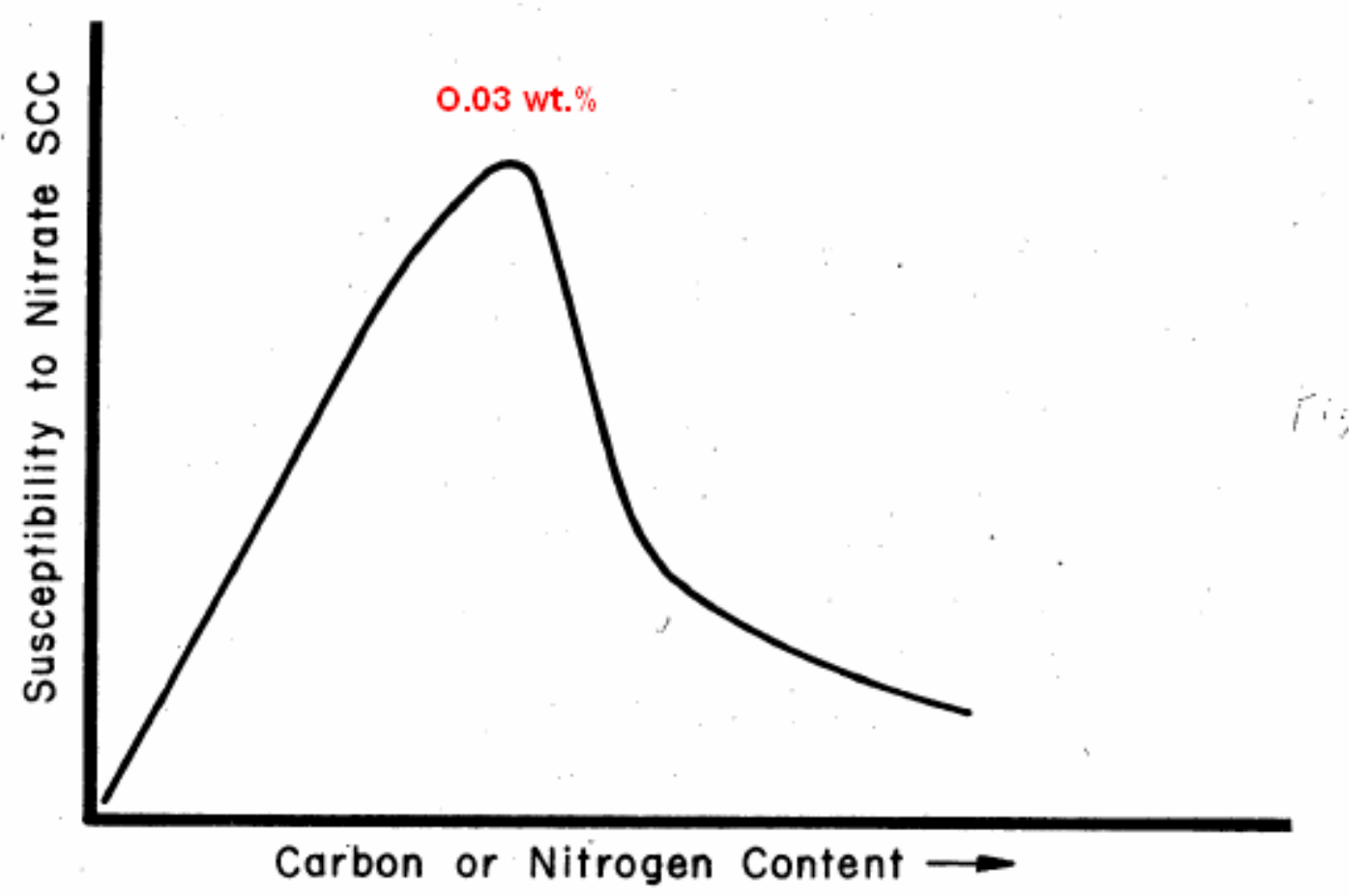

Figure 8. Susceptibility of carbon steel to nitrate SCC as a function of carbon or nitrogen content [9].

Another aspect of material structure that influences SCC behavior is the presence of grain boundaries. Grain boundaries are disordered interior surfaces of a metal and may act as preferential nucleation sites for second phase particles (See Figure 6). The result is a region that may have a different electrochemical response than the grain itself. The influence of grain size on strength characteristics of metals is generally given by the Petch-Hall relation: 


$$
\sigma_{\mathrm{y}}=\sigma_{\mathrm{i}}+\mathrm{kd}^{-0.5}
$$

where $\sigma_{\mathrm{y}}=$ yield strength, $\sigma_{\mathrm{i}}=$ lattice friction stress, $\mathrm{d}=$ grain diameter, and $\mathrm{k}=$ constant. Therefore the yield stress increases with a decrease in the grain size. A similar dependence of SCC susceptibility on grain size was found for mild steel in nitrate solutions. Figure 9 shows that the stress at which an SCC failure occurs increases as the grain size decreases [9]. It is theorized that SCC characteristics are controlled by the dislocation motion. The larger grains result in larger pile-ups of dislocations at barriers. The pile-ups subsequently initiate slip at lower applied stresses and expose new metal to the environment. Thus, smaller grain sizes result in an increase in both the yield strength and a greater resistance to SCC. Figure 6 shows that the A516/A212 microstructure has a much finer grain size than the A285 microstructure and Figure 5 also shows that the A212 material has the higher yield stress. It should be noted that the SCC susceptibility for steel in a caustic solution is also inversely proportional to the yield strength of the material [10]. Hence the material for the H-Area tanks again would be less susceptible to SCC than the material for the F-Area tanks.

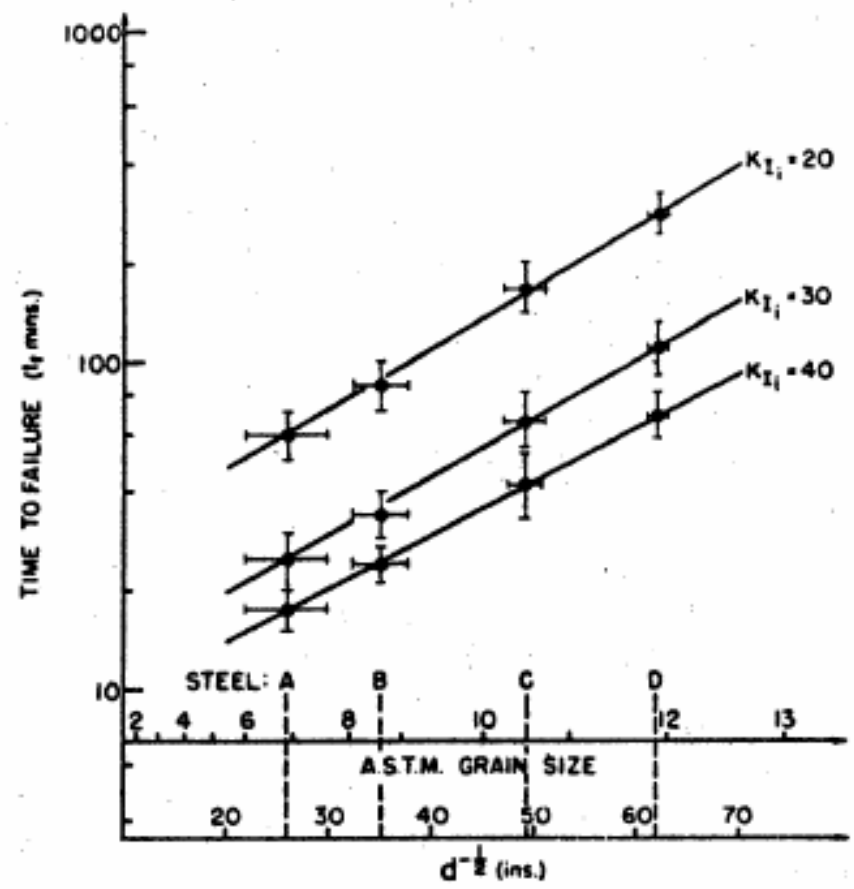

Figure 9. Time to failure as a function of grain size and initial stress intensity. [9]

The superiority of the A516/A212 material relative to A285 material was also demonstrated in laboratory tests [8]. Electrochemical slow strain rate tests were conducted on A285 and A516 materials in simulated waste environments at $100{ }^{\circ} \mathrm{C}$ and $0.5 \mathrm{~mA} / \mathrm{cm}^{2}$. The typical measures of SCC propensity, i.e. decrease in ductility as measured by elongation and reduction of area, indicated the A516 was much less susceptible than that observed for the A285. However, it should be noted that the A516 does still exhibit some degree of susceptibility to SCC. 
A final consideration in the assessment of the materials is the effect of residual or fabrication stresses on the SCC susceptibility. These stresses develop during the welding process. Welding involves heating the metal to its melting point with subsequent cooling and solidification. As a result, the metal contracts in a localized region near the weld and leads to built-in stresses that can exceed the yield stress of the metal and result in plastic deformation of the material [9]. Figure 10 shows the relationship between the stress parallel to a butt weld and the distance from the weld center line. Crack growth would cease once the residual stress falls below a certain level, approximately 1-2 inches in this figure. All cracks observed thus far in the waste tanks, including the Type IV tanks, have been associated with welds, weld repairs, or weld attachments. Residual stresses can be relieved by uniformly heating a structure to a sufficiently high temperature $\left(\sim 1100^{\circ} \mathrm{F}\right)$ to allow the built-in stresses in the metal to relax. Such heat treatment eliminates SCC by removing the stress. The effectiveness of stress relief was demonstrated in the laboratory on welded large plate samples [12]. On the basis of this work and other laboratory and industrial experience, the Type III waste tanks were heat treated after fabrication to relieve the residual stresses. However, neither the F-Area tanks nor the H-Area tanks were stressrelieved after welding. Thus it is anticipated that both sets of tanks are susceptible to SCC.

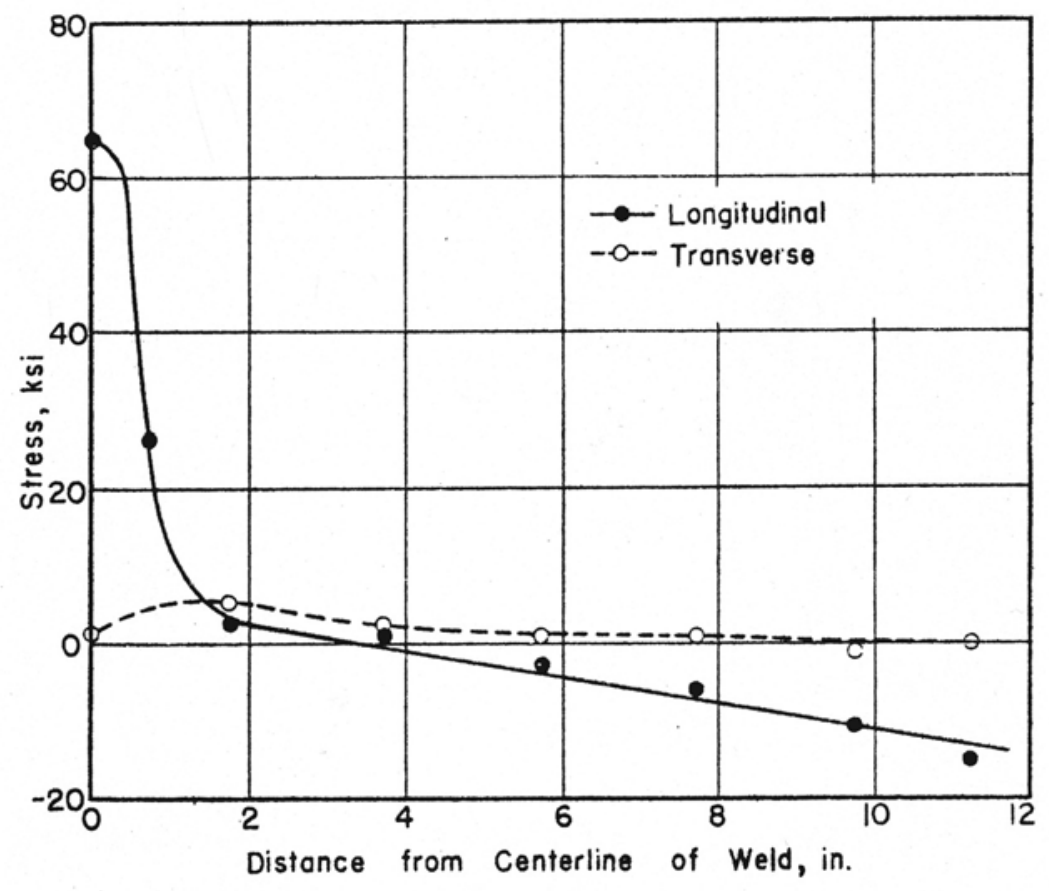

Figure 10. Distribution of residual stress in an as-welded specimen [9]. 


\subsection{Type IV Service History}

The service histories of F-Area tanks and H-Area tanks were reviewed to consider potential corrosion mechanisms on tanks in each area. The similarities and variations in their use are discussed in consideration of SCC suceptibility.

\subsubsection{F-Area}

Figure 11 summarizes the service history for Tanks 17-20 in F-Area. Tanks 18F, 19F, and 20F were operated differently from Tank $17 \mathrm{~F}$. For the aforementioned tanks, there are two distinct time periods in the history. From the time the tanks were placed in service in the early 1960's until the 1980's the primary function of these tanks was to store low heat waste generated from F-canyon. The 242-1F evaporator was utilized to concentrate the waste and to minimize the waste volume. Tank $18 \mathrm{~F}$ was utilized as the feed tank for the evaporator, while tanks $19 \mathrm{~F}$ and $20 \mathrm{~F}$ were utilized as evaporator receiver tanks. In order to minimize waste even further, concentrated salt solutions from Tanks $19 \mathrm{~F}$ and $20 \mathrm{~F}$ were decanted and recycled back to Tank $18 \mathrm{~F}$ where they were then processed through the evaporator several times over a 15 year period. The waste was not sampled during the 1960's (i.e., there was no corrosion control program at this time]; however, by the time samples were obtained in the 1970's, the hydroxide concentration had increased significantly in each of the tanks. For example, in 1974 the hydroxide concentrations in Tanks $19 \mathrm{~F}$ and $20 \mathrm{~F}$ were 7 and $8 \mathrm{M}$, respectively, while for Tank 18F the concentration was 5 M [13]. During a two year period between 1973 and 1975, the concentrated supernates from Tanks 19 and $20 \mathrm{~F}$ were decanted to Tank $18 \mathrm{~F}$ and recycled through the evaporator 10 times [14]. The build up of hydroxide in the system was consistent with laboratory observations [15] and other evaporator systems that were operated similarly [16]. In these cases, analyses of evaporated waste have shown a decrease in nitrate concentration and increase in hydroxide concentration in the supernate as the waste crystallizes in the tank. While the evaporated waste was dropped to Tanks $19 \mathrm{~F}$ and $20 \mathrm{~F}$, the supernate temperatures in the tank increased to 80 to $90{ }^{\circ} \mathrm{C}$. Figure 12 shows a temperature profile taken in one of the risers in Tank $20 \mathrm{~F}$ while evaporator concentrate was being transferred into the tank in 1974 [17]. The highest temperatures were in the upper regions of the tank where the concentrated supernate was located. The lower regions of the tanks contained crystallized salt. Because these tanks are not cooled, the temperature remained well above $70{ }^{\circ} \mathrm{C}$ for several years.

Tank $17 \mathrm{~F}$ was not utilized to recycle concentrate through the $242-1 \mathrm{~F}$ evaporator system during the early stages of the tank service history. Although it occasionally received concentrate from the system, the tank primarily received low heat waste from F-Canyon, which was then used to feed Tank 18F. The tank was not involved in the recycle of concentrated salt solutions to the evaporator. No samples of the waste were obtained during the 1960's (i.e., no corrosion control program at this time); however, in the mid 1970's a sample was taken and as seen in Figure 12, the nitrate and hydroxide concentrations are $3.3 \mathrm{M}$ and $1.8 \mathrm{M}$, respectively. It is interesting to note that although no formal corrosion program was in place, the waste in this tank would have been within the limits of the current corrosion control program. Tank temperatures were also generally less than $50^{\circ} \mathrm{C}$ at all times. 
In the 1980's the decision was made to proceed towards closure of these tanks. Salt dissolution and removal was performed in these tanks. Until the mid-1990's, a heel of ballast water was typically left in each of the four tanks to prevent the possibility of tank flotation in the perched water table. This ballast water was relatively dilute in concentration and consisted of inhibited water or waste from the reactor areas (See Figure 12). A corrosion control program was in place during this time, and for the most part the inhibitor concentrations were above the requirements [18]. The tank temperatures were less severe than early on in service; typically at the ambient temperature of $30{ }^{\circ} \mathrm{C}$ or less.

Closure of these tanks began in the late 1990's. Tanks 17F and 20F were closed in 1997. Bulk waste removal in tanks $18 \mathrm{~F}$ and $19 \mathrm{~F}$ was initiated in 2000 and final heel removal by mechanical cleaning methods is now on-going. No further use of these tanks is planned.

1962 to Mid 1980's for

Tanks $18 \mathrm{~F}, 19 \mathrm{~F}$, and $20 \mathrm{~F}$

- 10 to 20 years of storage of a blend of low heat and high heat waste; Evaporator concentrate, Canyon Low heat waste

- Waste Forms:

Supernate/Salt or

Supernate/Sludge

- Corrosion Chemistry Nitrate: $1.9-2.6 \mathrm{M}$ Nitrite: $0.74-1.6 \mathrm{M}$ Hydroxide: 5- $8 \mathrm{M}$

- SCC regime for corrosion chemistry; Supernate Temperature: $50-100{ }^{\circ} \mathrm{C}$

- Tank level changing frequently.
Mid 1980's to 2000 for Tank $18 \mathrm{~F}$ $\& 20 \mathrm{~F}$

- Waste Removal followed by approximately 20 years of storage of dilute inhibited waste. Tank 20F closed in 1997.

- Waste Forms: Supernate/Salt or Supernate/Sludge

- Corrosion Chemistry Nitrate: $0.06-0.08 \mathrm{M}$ Nitrite: $0.21-0.57 \mathrm{M}$ Hydroxide: 0.2-0.52 M

- Pitting regime for corrosion chemistry; All samples met corrosion inhibitor requirements for that time.

- Supernate Temperature: Ambient

- Tank level changing frequently.

Mid 1980's to 2000 for Tank 19F
- Waste Removal followed by
approximately 20 years of storage of
relatively dilute inhibited waste.
- Waste Forms: Supernate/Sludge
- Corrosion Chemistry
Nitrate: $1.5 \mathrm{M}$
Nitrite: $1.3 \mathrm{M}$
Hydroxide: $0.8 \mathrm{M}$
- SCC regime for corrosion
chemistry; All samples met corrosion
inhibitor requirements
- Supernate Temperature: Ambient
- Tank level changing frequently.

Mid 1980's to 1997 for Tank 17F

- Blend of evaporator concentrate and reactor area liquids and sludges

- Waste Forms: Supernate/Sludge

- Corrosion Chemistry

Nitrate: $0.03 \mathrm{M}$

Nitrite: $0.17 \mathrm{M}$

Hydroxide: $0.29 \mathrm{M}$

- Pitting regime for corrosion chemistry; All samples met corrosion inhibitor requirements

- Supernate Temperature: Ambient

Figure 11. F-Area Type IV tanks service history summary 


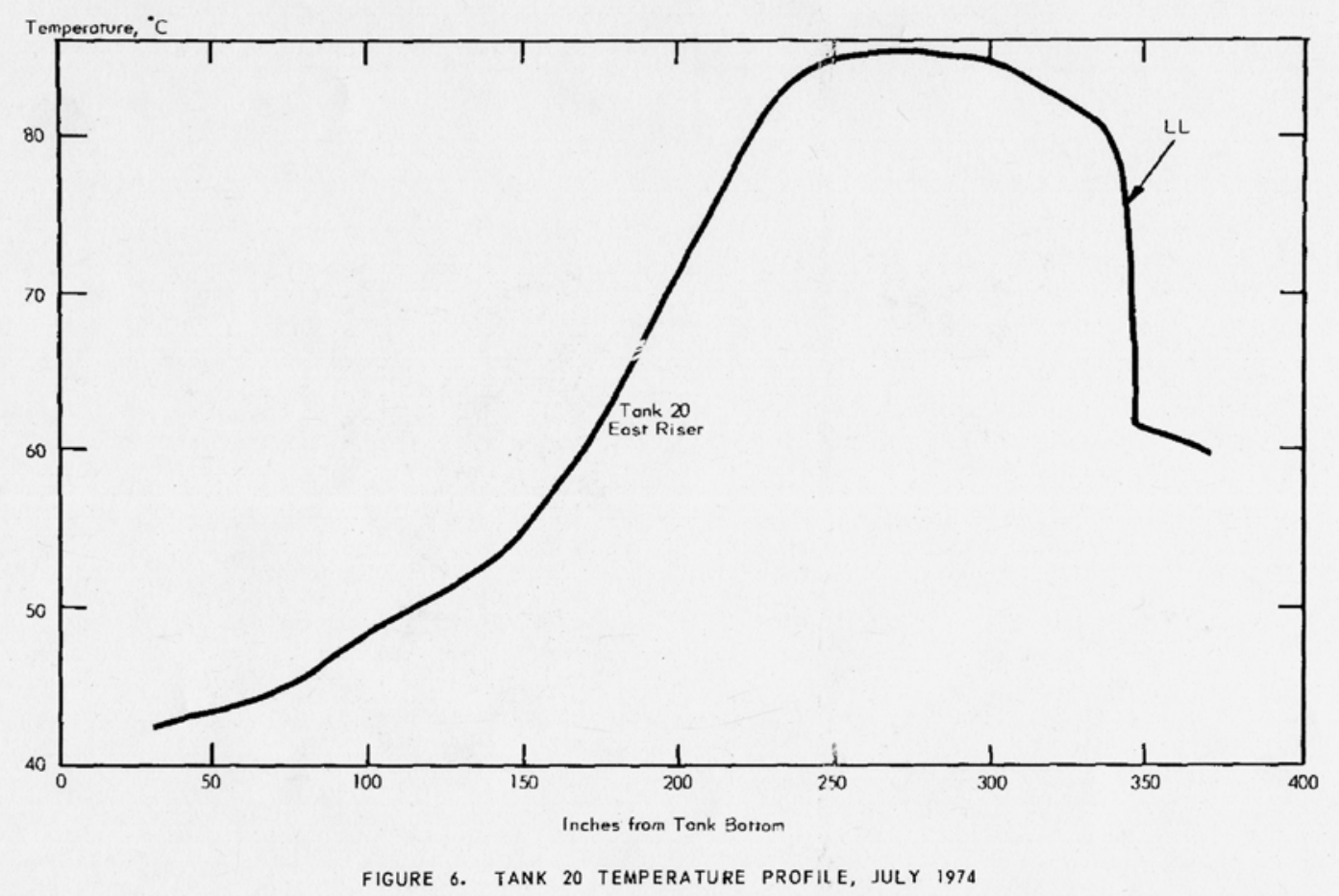

Figure 12. Tank 20F temperature profile ca. 1974 [16].

\subsection{2 $\underline{\text { H-Area }}$}

Figure 13 summarizes the service history for Tanks 21-24 in H-Area [19-22]. Tanks 21H [19], $22 \mathrm{H} \mathrm{[20]}$, and $24 \mathrm{H} \mathrm{[22]} \mathrm{were} \mathrm{operated} \mathrm{differently} \mathrm{than} \mathrm{Tank} 23 \mathrm{H} \mathrm{[21].} \mathrm{For} \mathrm{the} \mathrm{aforementioned}$ tanks, there are three distinct service periods in the history. From the time the tanks were placed in service in the early 1960's until the 1980's the primary function of these tanks was to store low-heat waste generated from H-canyon. The $242-1 \mathrm{H}$ evaporator was utilized to concentrate the waste and to minimize the waste volume. Tank $21 \mathrm{H}$ was utilized as the feed tank for the evaporator, while tanks $22 \mathrm{H} \mathrm{[20]}$ and $24 \mathrm{H} \mathrm{[22]} \mathrm{were} \mathrm{utilized} \mathrm{as} \mathrm{evaporator} \mathrm{receiver} \mathrm{tanks.}$ However, in contrast to the F-area tanks, the concentrated salt solutions were not recycled to Tank $21 \mathrm{H}$ and then processed through the evaporator. Therefore, no build-up of hydroxide in the concentrated supernate occurred. No samples of the waste were obtained during the 1960's (i.e., there was no corrosion control program at this time); however, the samples that were obtained in the 1970's were relatively high in nitrate (i.e., 2 to $5 \mathrm{M}$ ) and low in hydroxide (i.e., 1 to $2 \mathrm{M}$ ). It is interesting to note that although no formal corrosion program was in place, the waste in this tank would have been within the limits of the current corrosion control program. While the evaporated waste was dropped to Tanks $22 \mathrm{H} \mathrm{[20]}$ and $24 \mathrm{H} \mathrm{[22],} \mathrm{the} \mathrm{supernate} \mathrm{temperatures} \mathrm{in}$ the tank increased to 80 to $90{ }^{\circ} \mathrm{C}$; similar to Tanks $19 \mathrm{~F}$ and $20 \mathrm{~F}$. However, this temperature excursion occurred only once in Tank $24 \mathrm{H}$ and twice in Tank $22 \mathrm{H}$ and for a relatively short duration of time (i.e., 6 to 18 months). Because these tanks are not cooled, the temperature 
remained well above $70{ }^{\circ} \mathrm{C}$ for several years until salt removal was initiated in the 1970 's and 1980's.

From the mid-1980's to the mid-1990's these three tanks were utilized to store dilute wastes. The sources of this waste were the Receiving Basin for Off-site Fuel (RBOF) and pump bearing water. A corrosion control program was in place during this time, and for the most part the inhibitor concentrations were above the requirements [18]. The tank temperatures were less severe than early on in service; typically at the ambient temperature of $30^{\circ} \mathrm{C}$ or less.

Since the mid-1990's these three tanks have continued to store dilute waste; however, the primary source of the waste has changed. The waste has primarily consisted of recycle from the Defense Waste Processing Facility (DWPF). This stream has been carefully controlled and the inhibitor levels in these tanks have always been within the requirements of the corrosion control program. The tank temperatures were similar to what they had been the previous 10 years; typically at the ambient temperature of $30^{\circ} \mathrm{C}$ or less.

From 1964 to 2005, Tank 23H stored dilute wastes from the RBOF almost exclusively [21]. Although, there was no corrosion control program until the late 1970's, samples of waste taken since then have indicated that the inhibitor levels meet the requirements of the corrosion control program. Tank temperatures were typically near the ambient temperature of $30^{\circ} \mathrm{C}$. The unique aspect of the service history of this tank is that for a long period of time ( $>10$ years) in the 1960's and 1970's the tank level was low and constant. In the 1980's this changed as more frequent transfers from the RBOF occurred. In 2005, the RBOF was closed. Since then the liquid in Tank $23 \mathrm{H}$ has been utilized to store waste that will be fed to the Saltstone Facility.

\subsection{Inspection Results}

\subsubsection{F-Area}

In December 1983, three unusual "spots" were found on the walls of Tank 20F during a routine visual inspection [23]. All three spots were between 264 to 319 inches above the tank bottom [24]. Figure 14 shows the typical appearance of the unusual spots in Tank 20F. Inspections over a period of several months showed that these spots changed dimension with time and increased in size during rainy periods. These three spots are approximately 8 feet above the highest reported level of the water table. These three locations were later identified as leak sites. An additional leak site was discovered in 1990 at the 315 inch level. 
1962 to Mid 1980's

- 10 to 20 years of storage of a blend of low heat and high heat waste; Receiving Basin for Offsite Fuels (RBOF), Evaporator concentrate, Canyon Low heat waste

- Waste Forms: Supernate/Salt or Supernate/Sludge

- Corrosion Chemistry

Nitrate: 2-5 M

Nitrite: $0.1-0.2 \mathrm{M}$

Hydroxide: 1-2 M

- SCC regime for corrosion chemistry; No formal corrosion control program; Only 1/56 samples were outside corrosion control requirements.

- Supernate Temperature: 50 $100{ }^{\circ} \mathrm{C}$

- Tank level changing frequently.

\section{Mid 1980's to Mid 1990's}

- 10 years of waste removal followed by storage of dilute waste; Sources of dilute waste include: Receiving Basin for Off-site Fuels (RBOF) or pump bearing water.

- Waste Forms: Supernate/Salt or Supernate/Sludge

- Corrosion Chemistry Nitrate: $0.05-0.09 \mathrm{M}$ Nitrite: $0.14-0.23 \mathrm{M}$ Hydroxide: $0.14-0.32$ $\mathrm{M}$

- Pitting regime for corrosion chemistry; All samples met corrosion inhibitor requirements for that time.

- Supernate Temperature:

Ambient

- Tank level changing frequently.
Mid 1990's to Present

- 10 to 13 years of storage of a dilute waste; Primarily DWPF recycle

- Waste Forms:

Supernate/Sludge

- Corrosion Chemistry

Nitrate: 0.04-0.09 M

Nitrite: $0.18-0.37 \mathrm{M}$

Hydroxide: $0.3-0.5 \mathrm{M}$

- Pitting regime for corrosion

chemistry; All samples met

corrosion inhibitor requirements

- Supernate Temperature: Ambient

- Tank level changing

frequently.

(a)

Mid 1960's to Mid 2000's

- 40 years of storage of dilute low heat waste from the RBOF facility and effluent from the cesium removal column

- Waste Forms: Supernate/Sludge

- Corrosion Chemistry

Nitrate: $0.037 \mathrm{M}$

Nitrite: $0.11 \mathrm{M}$

Hydroxide: $0.13 \mathrm{M}$

- Pitting regime for corrosion chemistry; All samples met corrosion inhibitor requirements

- Supernate Temperature: Ambient

- Tank level less than half full for first 20 years or so; Tank level changed frequently over the last 20 years

(b)

Figure 13. H-Area Type IV tanks service history summary (a) Tanks 21H, 22H, and 24H; (b) Tank 23H 


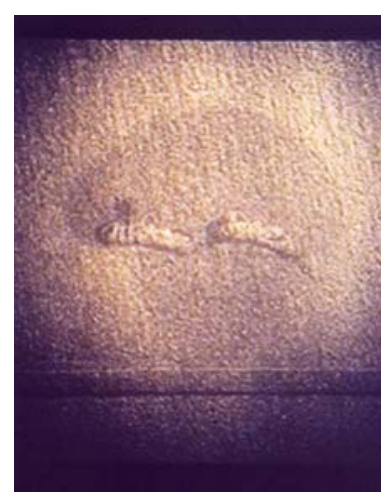

Figure 14. Visual appearance of leak site observed in Tank 20F.

In 1984, the spot beneath the north east riser, approximately 320 inches above the tank bottom was subjected to a close examination [23]. The spot shown in Figure 14 was grit-blasted with steel. Two tack welds were revealed at the precise location of the spot, each approximately 1.25 inches long and 0.625 inches wide. After blasting, a dark wet area was observed that was centered on the welds. Fluorescent dye was applied to the area and ultraviolet light revealed a dark streak between the welds. The streak resulted from water seeping through the wall and washing away the fluorescent dye. Application of the developer revealed several faint indications, but the origin of the leak (cracking or pitting) was not determined. It was also not possible from the inspection to determine whether the defect had initiated on the interior of the tank or on the exterior at the steel/concrete interface. However, the document does acknowledge that steel in contact with concrete would be passive so that contaminants in addition to moisture are necessary for corrosion. Other analyses which have investigated this possibility have shown that the groundwater at SRS is relatively benign and therefore relatively insignificant corrosion would occur [25].

Water ingress into the tank indicates that the concrete vault is not leak tight. Tank riser openings, transfer line penetrations, and construction joints are the most likely locations for water intrusion. White deposits in the areas of the defects indicate that calcium hydroxide is being leached from the concrete. The extent of leaching damage could not be seen due to the presence of the liner. However, leaching is also seen on the concrete dome of this and other Type IV tanks [26]. In all cases the leaching damage was considered to be minor.

In 1994, two leak sites were reported in Tank 19F. The leak sites were at the 315 inch and 337 inch level. There was evidence that the leak sites existed prior to 1994 (ca. 1988), however, several inspections done over a period of years had to be tracked to determine that in-leakage had occurred. Only visual inspections of these sites have been performed.

\subsubsection{H-Area}

A significant amount of rusting and tubercle formation was observed on the sidewalls of Tank $23 \mathrm{H}$ during an internal inspection in 1983. Figure 15 shows that the location of the damage was near the top of the tank where it had not been exposed to waste [21]. Further inspection was performed with a remote cleaning tool to determine the extent of damage due to pitting. 


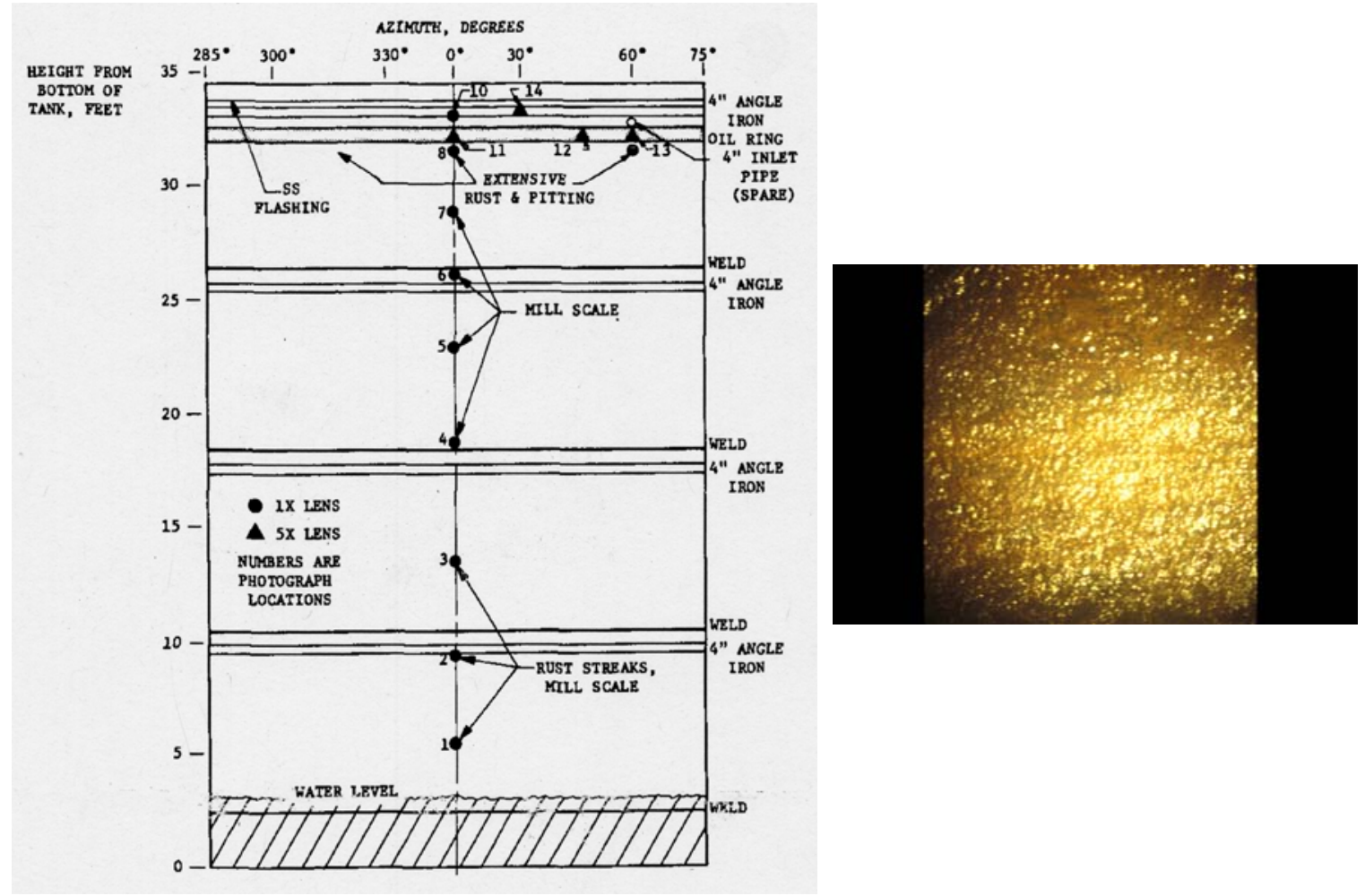

Figure 15. Location and appearance of pitting attack in Tank 23H [21].

After the walls were cleaned with steel grit an area approximately $1.5 \mathrm{ft}$ by $1.5 \mathrm{ft}$ was examined visually (see Figure 15). The cleaned walls had a rough generally corroded appearance. Mild pitting was noted but all the pits were shallow. None of the corrosion features observed precluded continued use of the waste tank. Annual inspections are performed in this area to verify that no additional attack has occurred. To date there has been no significant additional attack.

\subsection{Corrosion Mechanisms}

Significant general corrosion has not been observed either visually [27] or by ultrasonic measurements [28] of any of the types of tanks. However, leakage has been observed in several non-stress-relieved Type I and II tanks, in which salt deposits have been observed on the exterior of the primary tank wall via the annulus. The failure mechanism has been shown to be nitrate stress corrosion cracking [29].

Stress corrosion cracking occurs in metals and alloys due to the combined action of corrosion, stress and a susceptible material (See Figure 16). These variables must work in concert for the stress corrosion cracking mechanism to occur. If one of these variables is controlled, SCC can be mitigated. Mild steels are susceptible to SCC in nitrate solutions and in caustic solutions. It is generally agreed that the mechanism in both of these cases involves rupture of the passive oxide film at the metal surface due to strain followed by anodic dissolution at the grain 
boundaries [30]. In both cases the attack tends to follow the grain boundaries and hence is intergranular in nature (see Figure 17).

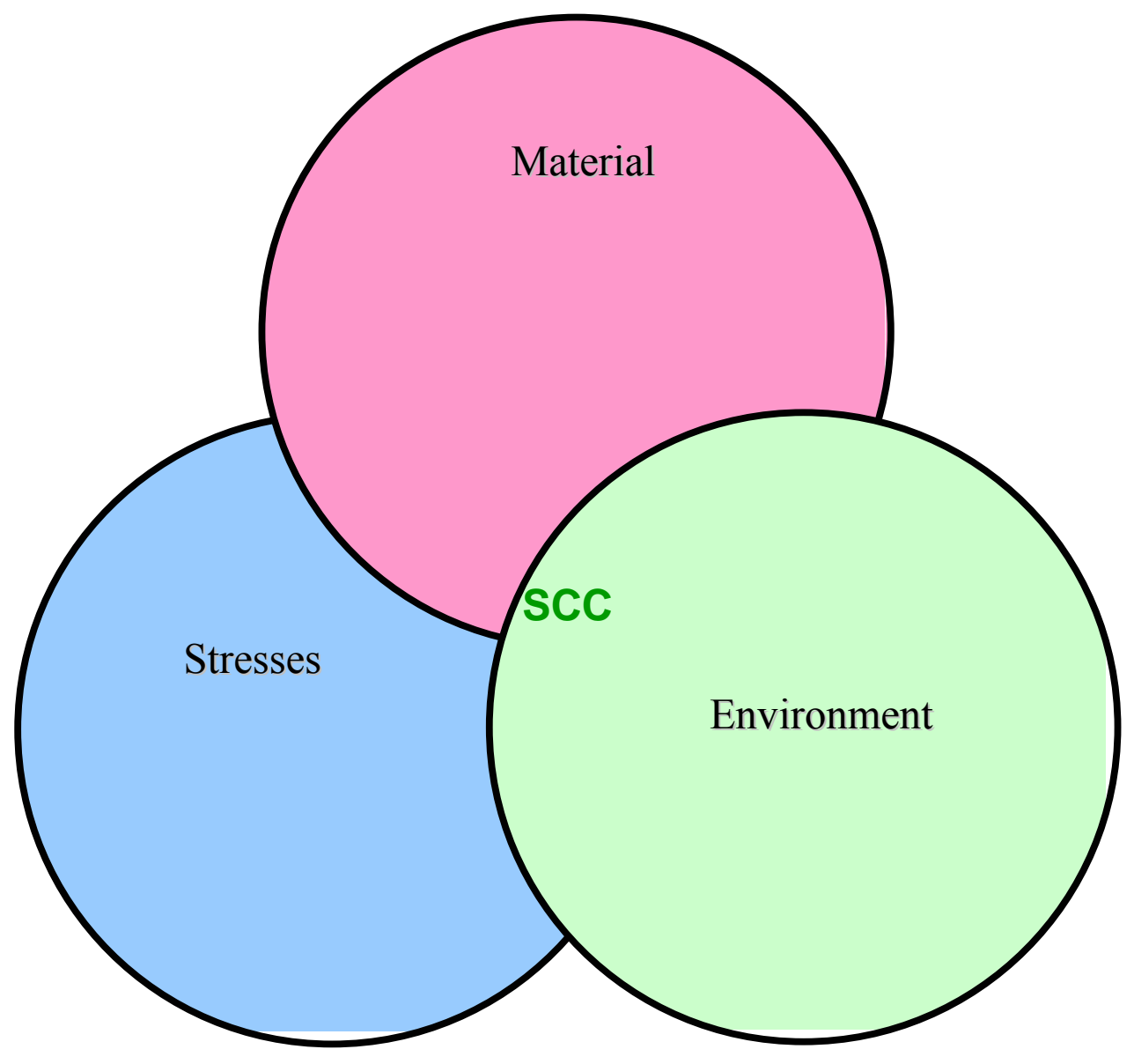

Figure 16. Variables influencing stress corrosion cracking. 


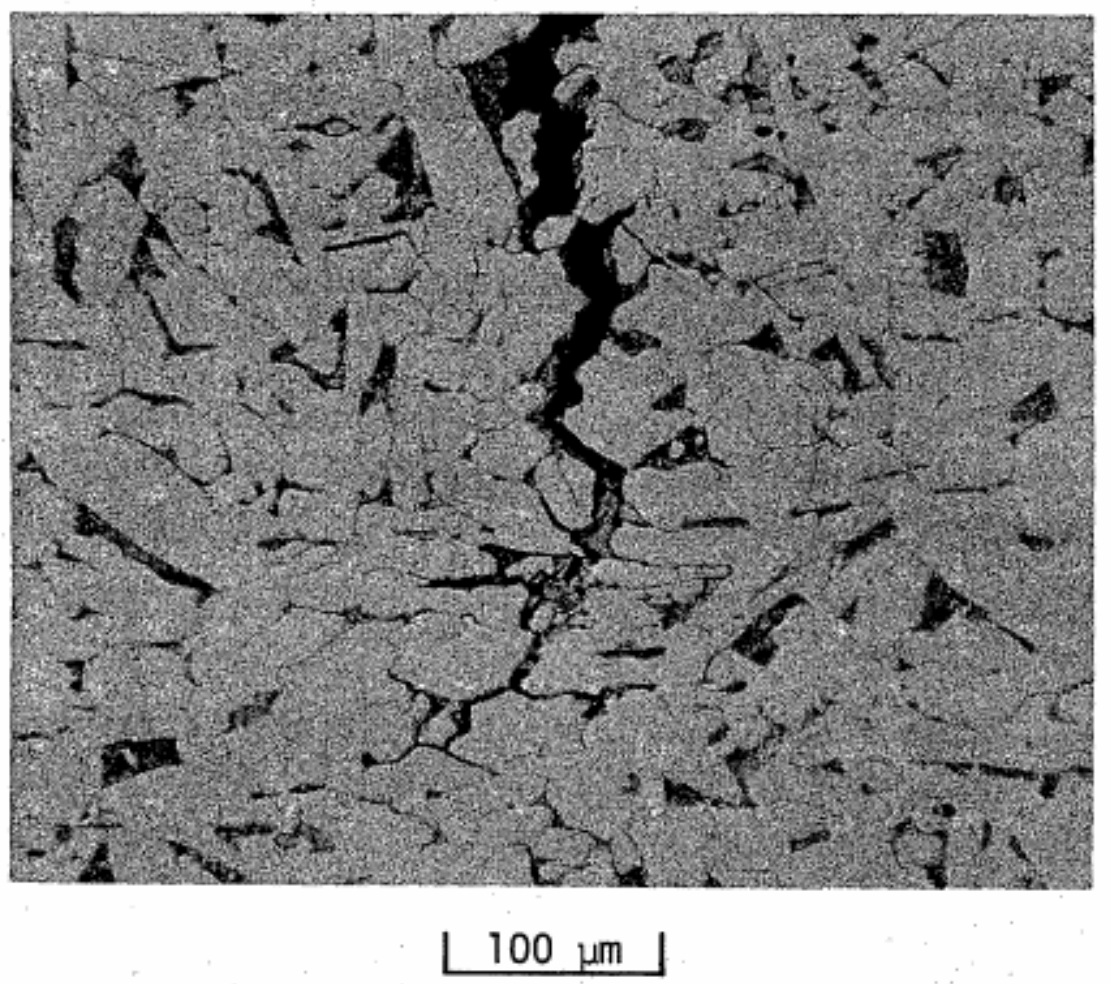

Figure 17. Intergranular stress corrosion cracking [8].

There are two primary differences between nitrate and caustic SCC. The first difference is electrochemical in nature and may be illustrated by plots of the current density versus potential otherwise known as polarization curves. Corrosion of a metal requires transfer of electrons (current flow) between anodic (oxidation) and cathodic (reduction) sites. Determination of the current density of a specimen in solution as a function of applied potential provides information about the maximum corrosion current, the system's tendency to passivate, and the open circuit potential. An example of polarization curves for actual waste from Tanks 11 and 12 and laboratory simulant are shown in Figure 18 [30]. The low current flow in the region between 0 and $0.3 \mathrm{~V}$ vs. SCE is a region of passivity where an oxide film is protecting the surface. However between $-0.2 \mathrm{~V}$ and $0 \mathrm{~V}$ vs. SCE the current increases rapidly and passes through a maximum current as the potential increases. This region of high currents is referred to as active. An active-to-passive transition as shown here is characteristic of systems susceptible to nitrate SCC. The propensity for nitrate SCC and caustic SCC can be determined due to the difference in the electrochemical potentials where the active-to-passive transition occurs for each. 


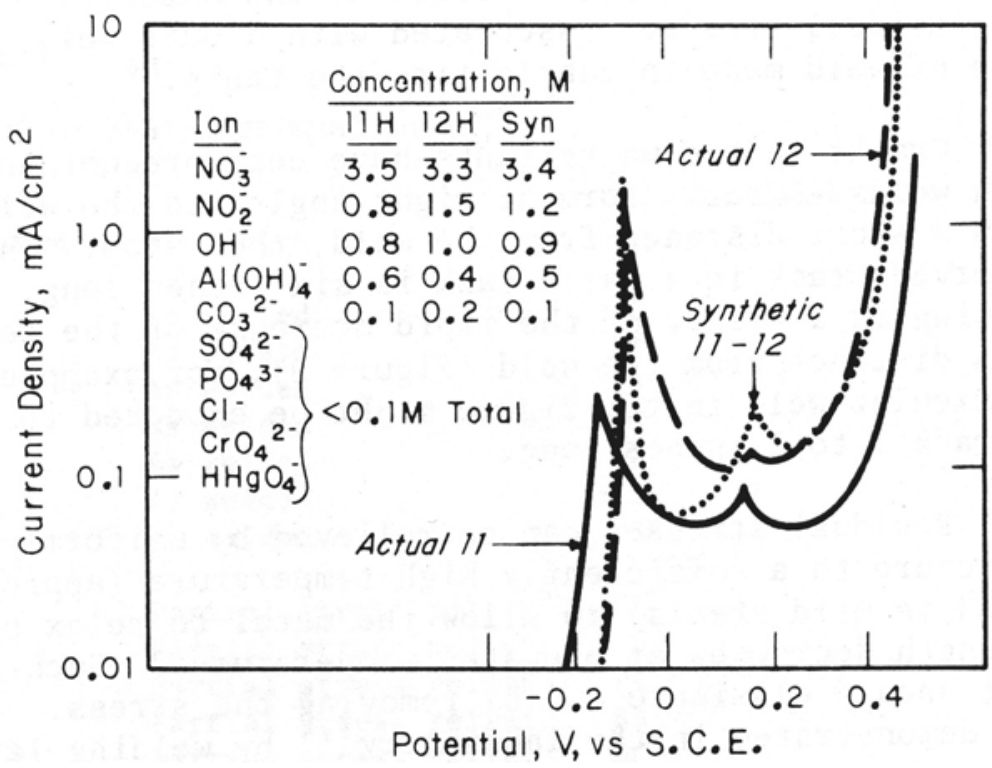

Figure 18. Anodic polarization curves for actual Tank $11 \mathrm{H}$ and $12 \mathrm{H}$ waste and a laboratory simulant [30].

The open circuit potential, the potential at zero current, is approximately $-0.2 \mathrm{~V}$ vs. SCE. This potential is within the range where nitrate SCC is known to occur (-0.3 V to $1.1 \mathrm{~V}$ vs. SCE) [30]. The potential for several of the tanks that received fresh waste was also measured and is shown in Table 1 [31]. Clearly the open circuit potentials are within the range where nitrate cracking is possible. It should be noted however, that sufficient inhibitor concentrations (i.e., nitrite and hydroxide) are present in these wastes to mitigate SCC [32]. Stress corrosion cracking likely occurred prior to sampling of the waste when there was no corrosion control program in place.

Table 1. Tank temperature, chemistry, and potential data for tanks which are susceptible to nitrate SCC.

\begin{tabular}{|l|l|l|l|l|l|l|}
\hline Tank & $\begin{array}{l}\text { Temperature } \\
\left({ }^{\circ} \mathrm{C}\right)\end{array}$ & $\begin{array}{l}\text { Nitrate } \\
(\mathrm{M})\end{array}$ & $\begin{array}{l}\text { Nitrite } \\
(\mathrm{M})\end{array}$ & $\begin{array}{l}\text { Hydroxide } \\
(\mathrm{M})\end{array}$ & $\begin{array}{l}\text { Potential } \\
(\mathrm{V} \text { vs. } \\
\text { SCE })\end{array}$ & $\begin{array}{l}\text { Cracking } \\
\text { Observed? }\end{array}$ \\
\hline $8 \mathrm{~F}$ & 40 & 1.7 & 0.5 & 1.1 & -0.120 & No \\
\hline $11 \mathrm{H}$ & 49 & 3.7 & 0.8 & 0.6 & -0.085 & Yes \\
\hline $15 \mathrm{H}$ & 48 & 3.6 & 1.1 & 1.0 & -0.065 & Yes \\
\hline
\end{tabular}

Polarization scans for waste typical of evaporator systems are shown in Figure 19. The scan that represents the electrochemical behavior of steel in actual wastes taken from Tanks 18, 19 and 20 demonstrates an active-passive transition as well. However, the open circuit potential and the potential of the current maximum have shifted towards more negative potentials. Ondrejcin noted that this type of behavior has been reported for greater than $6 \mathrm{M}$ hydroxide solutions [13]. In contrast, waste from Tanks $17 \mathrm{~F}, 22 \mathrm{H}$, and $24 \mathrm{H}$ do not exhibit the active to passive transition. These wastes had a relatively low hydroxide concentration (i.e., 1-2 M) and a relatively high 
nitrate concentration (i.e., 2-5 M). The result is a stable passive state that will exhibit a low general corrosion rate.

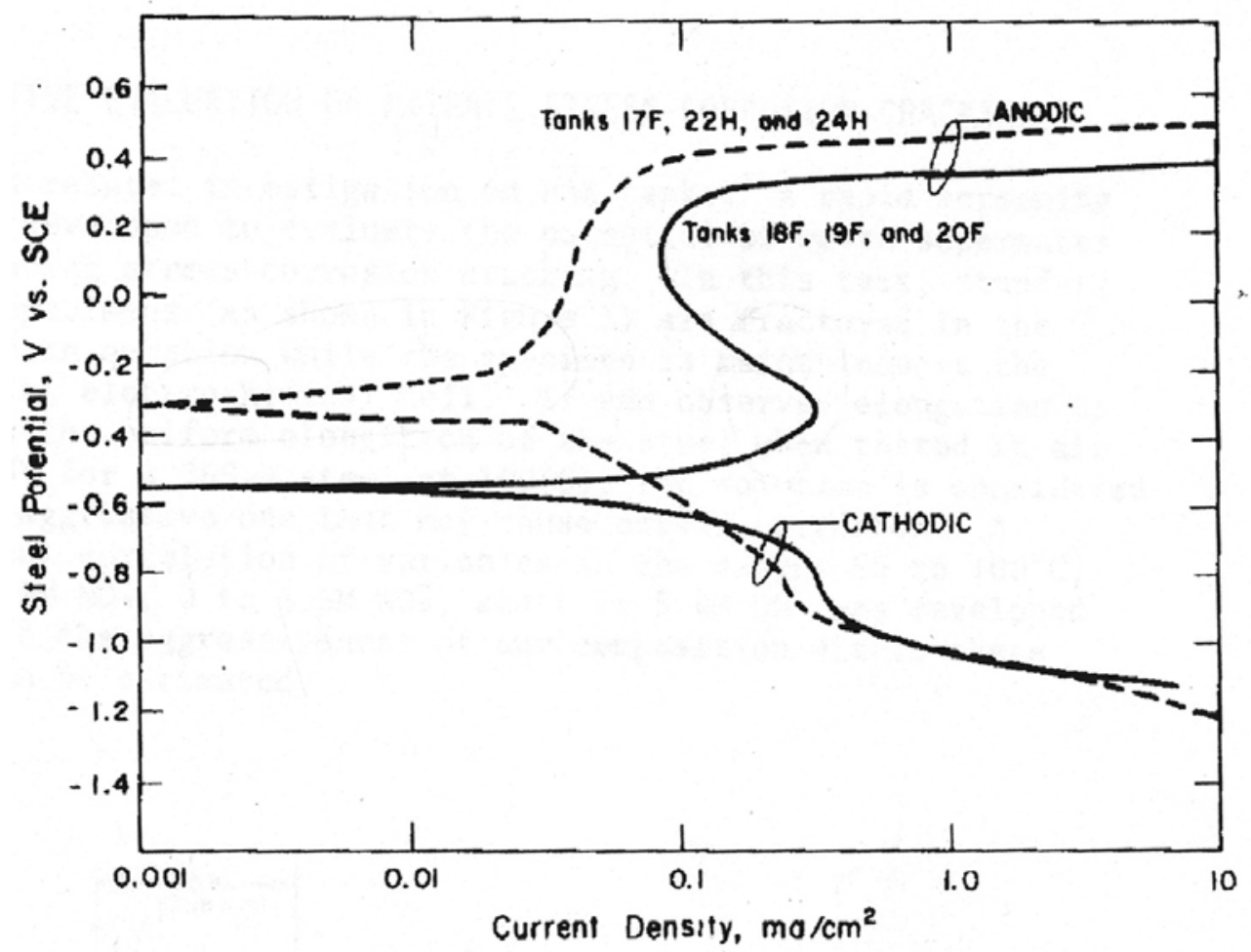

Figure 19. Anodic polarization scans for wastes stored in Type IV tanks [13].

Subramanian and Mickalonis also observed this behavior in high caustic, relatively low nitrate solutions [33]. The anodic polarization behavior of ASTM A516-70, was determined in solutions with $10 \mathrm{M} \mathrm{NaOH}$ and various concentrations of $\mathrm{NaNO}_{3}(0.01-2.0 \mathrm{M})$. The test results revealed that with various additions of sodium nitrate, a strong oxidizer, the active-to-passive transition peak was suppressed (i.e., the open circuit potential shifted toward positive potentials). The results indicate that the active-passive transition peak seen in $10 \mathrm{M} \mathrm{NaOH}$, typically associated with caustic SCC at $-0.25 \mathrm{~V}-\mathrm{SCE}$ and $-0.75 \mathrm{~V}-\mathrm{SCE}$ is still present at the lower $(<0.5$ $\mathrm{M})$ and higher $(>2 \mathrm{M})$ concentrations of nitrate. However, there is a mid-range of nitrate concentrations within which the peak is not present, because the corrosion potential ( $\left.\mathrm{E}_{\mathrm{corr}}\right)$ shifts above the transition potential. The range of sodium nitrate concentrations over which the $\mathrm{E}_{\text {corr }}$ is driven beyond the active-passive transition peaks is dependent upon temperature, as shown in Figure 20. At lower levels of nitrate additions, $\mathrm{E}_{\text {corr }}$ is not sufficiently affected to suppress the initial active-passive transition peak. The $\mathrm{E}_{\text {corr }}$ is polarized above the initial peak with additional sodium nitrate additions, but returns to more active potentials at a concentration of $2 \mathrm{M}$ sodium nitrate. 


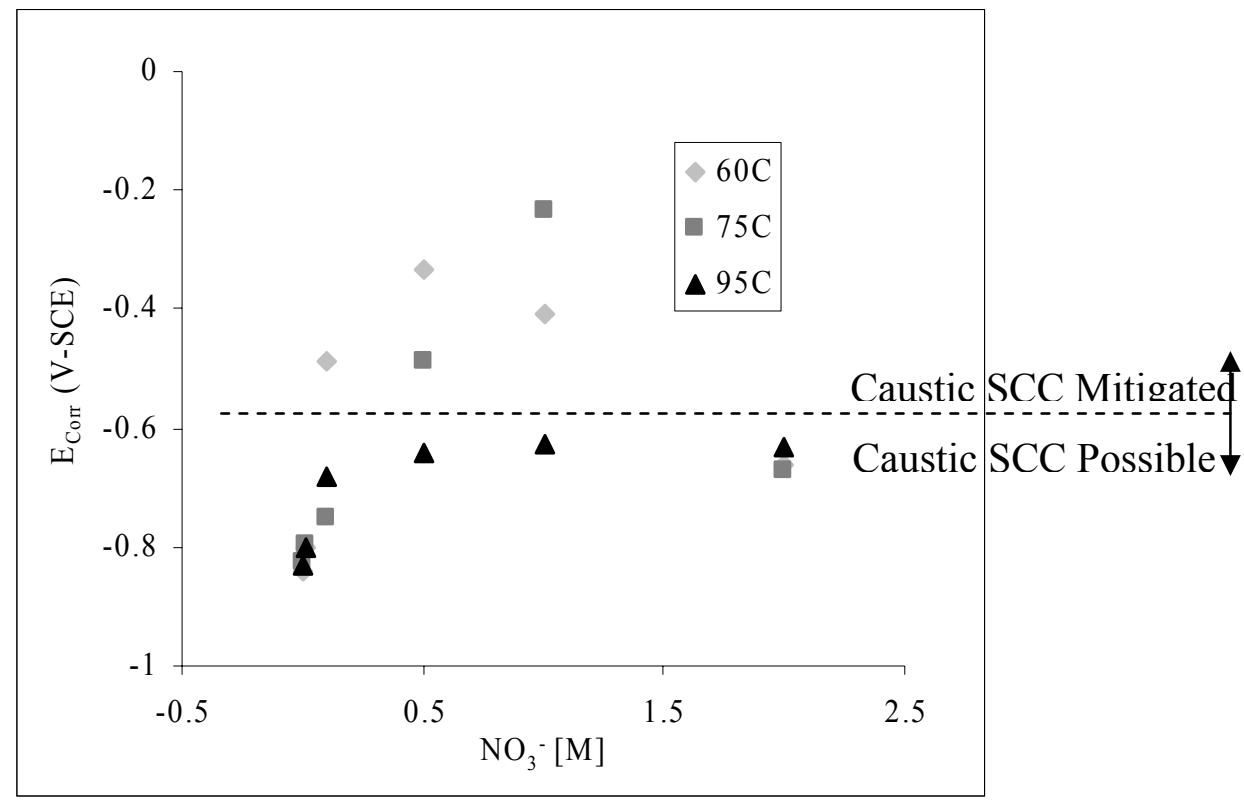

Figure 20. $\mathrm{E}_{\mathrm{Corr}}$ as a function of temperature and nitrate additions to $10 \mathrm{M} \mathrm{NaOH}$ [33].

The return of the $\mathrm{E}_{\text {corr }}$ to lower values at higher nitrate concentrations was attributed to a synergistic and competitive mechanism between oxygen and nitrate reduction for the cathodic reaction. Cathodic polarization scans performed at high sodium nitrate concentration (2M) shows similar results to those of the de-aerated or high temperature solutions with low dissolved oxygen content. The data suggests that the ionic strength of the solution has become too high to support a sufficient amount of dissolved oxygen to support the oxygen reduction reaction. Figure 20 also shows that at higher temperatures no nitrate concentration was able to suppress the active-to passive peak. Therefore in these high ionic strength solutions at some temperature between $75^{\circ} \mathrm{C}$ and $95^{\circ} \mathrm{C}$ it is electrochemically possible for caustic SCC to occur. It should be noted however, that the maximum current density in the active-to-passive region was suppressed slightly indicating some degree of inhibition.

The second difference between nitrate SCC and caustic SCC is the temperature at which it occurs. Nitrate SCC has been observed in the laboratory at temperatures on the order of $50{ }^{\circ} \mathrm{C}$. Indeed the supernate temperatures in most of the tanks that cracked while receiving waste directly from the canyons were in the $50-60{ }^{\circ} \mathrm{C}$ range. Caustic SCC on the other hand tends to occur in solutions that are closer to $100^{\circ} \mathrm{C}[30]$.

These two factors suggest that the upper region of Tanks 18F, 19F, and 20F might be susceptible to caustic SCC. High temperatures occurred in this region and the hydroxide concentrations were elevated over an extended period of time. The inspection results bear this hypothesis out, as all the leak sites in Tanks 19 and 20F were discovered in this region. No leak sites were discovered in Tank 18F; however, the hydroxide concentration was lower in this tank (5 M) than in the other two tanks and the supernate temperature was lower due to the fact that the tank did not receive waste directly from the evaporator. These environments did not exist in Tanks 21$24 \mathrm{H}$ (or 17F), and therefore cracking has not been observed. 


\subsection{Conclusions}

Data from the construction of the tanks (i.e., certified mill test reports for the steel, no stressrelief), the service history (i.e., waste sample data, temperature data), laboratory tests on actual wastes and simulants (i.e., electrochemical testing), and the results of the visual inspections were reviewed. The following observations and conclusions were made:

1) Comparison of the compositional and microstructural features indicate that the $\mathrm{A} 212$ material utilized for construction of the H-Area tanks are far more resistant to SCC than the A285 materials used for construction of the F-Area tanks.

2) A review of the materials of construction, temperature history, service histories concluded that F-Area tanks likely failed by caustic stress corrosion cracking.

3) The environment in the F-Area tanks was more aggressive than that experienced by the H-Area tanks.

4) Based on a review of the service history, the H-Area tanks have not been exposed to an environment that would render the tanks susceptible to either nitrate stress corrosion cracking (i.e., the cause of failures in the Type I and II tanks) or caustic stress corrosion cracking.

5) Due to the very dilute and uninhibited solutions that have been stored in Tank $23 \mathrm{H}$, vapor space corrosion has occurred on some of areas of the liner. The mild pitting that was observed is broad and shallow and has no structural impact. Further significant pit growth has not been observed since the 1980's.

\subsection{References}

1. M. R. Simpson to D. B. Jett, "Construction and Operations Summary: Tanks 21 and $24-$ H-Area", August 9, 1973.

2. W. C. Rion to E. A. Hein, "Bldg. 241F-Waste Storage Tank- Steel Tank LinerSummary of Steel Compositions and Properties", April 8, 1964.

3. W. C. Rion to E. A. Hein, "Bldg. 241H-Waste Storage Tank- Steel Tank LinerSummary of Steel Compositions and Properties", April 6, 1964.

4. B. E. Loper, "Liquid Waste Tank Structural Design Concept", DPE-3477, Section III.N, June 21, 1977.

5. G. R. Caskey, "Potential Radiation Damage - Storage Tanks for Liquid Radioactive Waste", August 1992.

6. W. B. DeLong to S. P. Rideout, "Properties of A516-70 Steel Used in Waste Tanks 29-32", September 10, 1974.

7. W. B. DeLong to R. G. Garvin, "FY'74 Waste Tanks Proj. 1463", August 6, 1975.

8. R. S. Ondrejcin, "Prediction of Stress Corrosion of Carbon Steel by Nuclear Process Liquid Wastes", DP-1478, August, 1978.

9. J. A. Donovan, "Metallurgy of Stress Corrosion Cracking” DP-MS-75-36, June, 1975. 
10. P. G. Sarafian, "The Influence of Microstructure on Stress Corrosion Cracking of Mild Steel in Synthetic Caustic-Nitrate Nuclear Waste Solution”, DP-MS-76-15, December, 1975.

11. New Reference.

12. L. P. Costas, M. L. Holzworth, and W. C. Rion, "Stress Corrosion Cracking of Carbon Steels in Simulated Waste Solutions", DP-1023, June 1966.

13. R. S. Ondrejcin, "Composition and Corrosiveness of Low-Activity Waste Supernates Stored at the Savannah River Site", DP-1427, October 1976.

14. W. S. Cavin, "Waste Transfers and Miscellaneous Additions", WSRC-TR-93425, Rev. 1, January 24, 1994.

15. C. B. Goodlett, "Concentration of Radioactive Wastes", DP-1135, June 1968.

16. R. S. Ondrejcin, "Chemical Compositions of Supernate Stored in SRP High Level Waste Tanks", DP-1347, August, 1974.

17. F. G. McNatt, "History of Waste Tank 20: 1959 Through 1974”, DPSPU 82-1110, July 1982.

18. P. E. Zapp and D. T. Hobbs, "Application of Technical Standard DPSTS-2415.03 to Type IV Waste Tanks Containing Ballast Water", WSRC-TR-91-59, February 28, 1991.

19. F. G. McNatt, "History of Waste Tank 21: 1961 Through 1974”, DPSPU-78-1110, October 1978.

20. F. G. McNatt, "History of Waste Tank 22: 1965 Through 1974”, DPSPU 79-11-5, April 1979.

21. F. G. McNatt, "History of Waste Tank 23: 1962 Through 1974", DPSPU 79-11-7, April 1979.

22. F. G. McNatt, "History of Waste Tank 24: 1962 Through 1974", DPSPU 79-11-2, April 1979.

23. C. F. Jenkins and P. S. Bird, "Dye Penetrant Inspections of Internal Walls, Waste Tanks 17, 20, 23", DPSPU-85-11-4, September 1985.

24. R. S. Waltz, "SRS High Level Waste Tank Leaksite Information”, C-ESR-G00003, Rev. 2, February 14, 2006.

25. K. H. Subramanian, "Life Estimation of High Level Waste Tanks Steel for FTank Farm Closure Performance Assessment, Rev. 1”, WSRC-STI-2007-00061, Rev. 1, October 2007.

26. B. J. Wiersma and M. S. Shurrab, "A Visual Assessment of the Concrete Vaults which Surround Underground Waste Storage Tanks", WSRC-TR-93-761, December 1993.

27. R. S. Waltz and W. R. West, "Annual Radioactive Waste Tank Inspection Program - 2006”, WSRC-TR-2007-00094, June 2007.

28. J. B. Elder, "Tank Inspection NDE Results for Fiscal Year 2007 Including Waste Tanks 35, 36, 37, 38, and 15", WSRC-TR-2007-00064, September 27, 2007.

29. R. M. Girdler, "Leaks in Radioactive Waste Tanks", DP-990, December 1965.

30. J. A. Donovan, "Materials Aspects of SRP Waste Storage - Corrosion and Mechanical Failure", DP-1476, November 1977.

31. "Savannah River Laboratory Quarterly Report: Waste Management”, DPST-73125-2, April-June 1973. 
32. "CSTF Corrosion Control Program: Program Description Document", WSRCTR-2003-00327, Rev. 4, December 2007.

33. K.H. Subramanian and J. I. Mickalonis, "Anodic Polarization Behavior of LowCarbon Steel in Concentrated Sodium Hydroxide with Sodium Nitrate Additions," WSRC-TR-2004-00292, October 2004. 